\title{
The Phenomenon of Climate Change in Organization and HR- Related Literature: A Conceptual Brief Analysis
}

Mohamed MOUSA, Estonian Business School, Tallinn, Estonia, Mohamed.mousa@ebs.ee

\begin{abstract}
Climate change has become one of the main challenges facing humanity. Over the past decade, this phenomenon, which may have been caused by natural variability and/or human activity, has attracted many scholars from different scientific disciplines to warn of its potential consequences. The author of this paper has decided to address the existence of this important phenomenon in organizational literature. However, upon exploring different academic databases, the rarity of research focusing on climate change and its relationship and/or effect on HR or organizational aspects became obvious. Accordingly, the author recommends other HR and organizational scholars devote considerable space to this phenomenon in their field.
\end{abstract}

Keywords: climate; climate change; organization- related literature; HR- related literature

JEL Classification: M14.

\section{Introduction}

Over the past 5 years climate change has been considered one of the main buzzwords in both socio-political and socio-economic spheres. Consequently, many policymakers and regulators have asserted its importance in deciding the near future of humanity (Vaara et al., 2010, Saba et al., 2013). Moreover, Zakaria (2014) highlights its role in shaping international peace between countries. Consequently, it has become common to touch on attempts undertaken by governments, various businesses, environmental lobby groups besides other social actors in adopting, managing or maybe in some cases mitigating any expected risks of this phenomenon (Ferguson et al., 2016).

Despite the fact that climate change is a global challenge that may entail risks and opportunities (Winn et al., 2010), the response to this phenomenon changes from country to country. For instance, the UK has established both the UK Emissions Trading Scheme (UK ETS) and the Mandatory Carbon Reduction 
Commitment (CRC) as a serious attempt to foster environmental- stewardship roles among companies (Ferguson et al., 2016). However, developing countries have not been seen to develop their own anti-carbon emission business plans or promote environment friendly initiatives in their different local regions or within their borders (Begum \& Pereira, 2011). It is worth mentioning here that both the World Bank and the United Nations framework convention on climate change (UNFCCC) organize regular meetings besides funding project activities responding to climate change, especially those established in developing nations (Saba et al., 2013).

\section{Literature review. Comparative analysis}

Climate change has been defined by Saba et al. (2013) as any change in climate over time that occurs as a result of human activity or natural variability. Accordingly, in the case of natural variability, this change in climate may include, and not be limited to, increases in global temperatures and rising sea levels besides other catastrophic environmental aspects such as storms, hurricanes, cyclones, flooding, bushfires and others (Winn et al., 2010), whereas in the case of human activity, changes in climate may include the increase of carbon emissions. Linnenluecke and Griffiths (2012) dichotomise climate change as usual (e.g. rainfall) and extreme (e.g. hurricanes). Nonetheless, Nurunnabi (2016) asserts that however we classify it, climate change entails a noticeable effect on the food, air and water different people consume.

Like countries, organizations have reacted differently to the phenomenon of climate change. Kiron et al. (2013) indicate that a small number of organizations have handled climate change comprehensively by collecting, analysing and reporting information about climate change and its effect on current and potential business-related activities, while the tendency in a larger number of organizations is to include some environmental information in their annual reports as a kind of social luxury or as a way of branding the organization as environmentally friendly. Therefore, and in spite of elaborations by Hoffman et al. (2009) that some business activities like construction, mining, agriculture, tourism, insurance and many more will be negatively impacted by climate change, there appears to be three main approaches to climate change at the organizational level.

- The first approach involves mitigating climate-change risks through building a business case for handling environmental related aspects (Spence, 
2007). According to this approach, organizations act as active social leaders that display a balanced concern for safeguarding the environment and subsequently protecting human lives on the one hand, and expecting to yield additional economic returns from their environmentally friendly behaviour on the other.

- The second approach involves believing in the inconsiderable effect that environmental biophysical change has on both the globe and economic prosperity (Hoffman, 2006). Apparently, the majority of organizations that adopt this approach pay very little attention to their surrounding environment.

- The third organizational approach includes intentionally ignoring all environmental aspects either because of their insignificance in their economic activity or due to the profit-oriented culture they trust and employ. Noticeably, this group of organizations exists almost exclusively in developing economies.

Apparently and upon examining different relevant academic databases, the author of the present paper has prepared the following table in which he summarizes the main, if not all, studies conducted on climate change in the context of organizational literature.

Table 1. The main studies addressing climate change in organizational literature

\begin{tabular}{|l|l|l|l|l|}
\hline Reference & Country & Methodology & Findings & Recommendations \\
\hline Begum, R.A. \& & Malaysia & The authors & 70\% of & There is a need to \\
Pereira, J.J. & & conducted face- & Malaysian & motivate \\
(2015). The & & to- face & managers think & managerial \\
awareness, & & interviews with & that climate & awareness of \\
perception and & & senior & change might & climate change \\
motivational & & managers in & affect company & using financial \\
analysis of & & companies that & profits whereas, & incentives, training, \\
climate change & & are members of & 96\% of the & research and \\
and business & & the Malaysian & participants & development \\
perspectives in & & International & believe that this & besides relevant \\
Malaysia. & & Chambers of & change in & legislation. \\
Mitigation and & & Commerce and & climate will not & \\
Adaptation & & Industry (MICCI) & affect the & \\
Strategies for & & besides & Malaysian & \\
Global Change, & & preparing a & economy. & \\
20. Pp. 361-370. & & survey and & Additionally, & \\
& & collecting data & 71\% of the & \\
& through this & participants & \\
& & survey and then & think that the & \\
& analysing this & business & \\
& & &
\end{tabular}




\begin{tabular}{|c|c|c|c|c|}
\hline & & $\begin{array}{l}\text { data through a } \\
\text { weighted } \\
\text { average model. }\end{array}$ & $\begin{array}{l}\text { activities of their } \\
\text { company have } \\
\text { no effect on } \\
\text { climate change. }\end{array}$ & \\
\hline $\begin{array}{l}\text { Gonzalez- } \\
\text { Gonzalez, J.M. \& } \\
\text { Zamora- Ramirez, } \\
\text { C. (2016). } \\
\text { Organizational } \\
\text { communication } \\
\text { on climate } \\
\text { change: the } \\
\text { influence of the } \\
\text { institutional } \\
\text { context and the } \\
\text { adoption pattern. } \\
\text { International } \\
\text { Journal of } \\
\text { Climate Change } \\
\text { Strategies and } \\
\text { Management } 8 \\
\text { (2). Pp. 286-316. }\end{array}$ & Spain & $\begin{array}{l}\text { Qualitative. } \\
\text { Analysis of } 4 \\
\text { Spanish } \\
\text { companies that } \\
\text { work in } \\
\text { different fields. }\end{array}$ & $\begin{array}{l}\text { Determining the } \\
\text { approach to } \\
\text { carbon reporting } \\
\text { (outside-in, } \\
\text { inside-out, twin- } \\
\text { track and } \\
\text { isolated) } \\
\text { depends on } \\
\text { both the } \\
\text { companies' } \\
\text { institutional } \\
\text { context } \\
\text { (regulative, } \\
\text { normative and } \\
\text { cognitive) along } \\
\text { with the usable } \\
\text { organizational } \\
\text { adoption } \\
\text { pattern to } \\
\text { control carbon } \\
\text { emissions } \\
\text { (substantive or } \\
\text { symbolic). }\end{array}$ & $\begin{array}{l}\text { No } \\
\text { recommendations } \\
\text { provided }\end{array}$ \\
\hline $\begin{array}{l}\text { Ferguson, J., } \\
\text { Aguiar, T.R.S.D. \& } \\
\text { Fearfull, A. } \\
\text { (2016). Corporate } \\
\text { response to } \\
\text { climate change: } \\
\text { language, power } \\
\text { and symbolic } \\
\text { construction. } \\
\text { Accounting, } \\
\text { Auditing \& } \\
\text { Accountability } \\
\text { Journal } 29 \text { (2). Pp. } \\
\text { 278-304. }\end{array}$ & $\begin{array}{l}\text { United } \\
\text { Kingdom }\end{array}$ & $\begin{array}{l}\text { Analysis of } 99 \\
\text { stand-alone } \\
\text { reports of } \\
\text { different } \\
\text { companies that } \\
\text { have } \\
\text { participated in } \\
\text { UK ETS and CRC } \\
\text { over the past } 9 \\
\text { years. }\end{array}$ & $\begin{array}{l}\text { Every company } \\
\text { prefers to use a } \\
\text { particular } \\
\text { linguistic } \\
\text { strategy when } \\
\text { reporting about } \\
\text { climate change. } \\
\text { Moreover, the } \\
\text { companies } \\
\text { prefer to } \\
\text { participate } \\
\text { voluntarily in } \\
\text { and report on } \\
\text { their climate } \\
\text { change } \\
\text { initiatives. }\end{array}$ & $\begin{array}{l}\text { No } \\
\text { recommendations } \\
\text { provided }\end{array}$ \\
\hline $\begin{array}{l}\text { Nurunnabi, M. } \\
\text { (2016). Who } \\
\text { cares about } \\
\text { climate change }\end{array}$ & Bangladesh & $\begin{array}{l}\text { Qualitative. } \\
\text { Reviews and } \\
\text { evaluations of } \\
32 \text { semi- }\end{array}$ & $\begin{array}{l}\text { Given their } \\
\text { market position, } \\
\text { large companies } \\
\text { pay more }\end{array}$ & $\begin{array}{l}\text { The Bangladeshi } \\
\text { government should } \\
\text { collaborate with } \\
\text { local businesses in }\end{array}$ \\
\hline
\end{tabular}




\begin{tabular}{|c|c|c|c|}
\hline $\begin{array}{l}\text { reporting in } \\
\text { developing } \\
\text { countries? The } \\
\text { market response } \\
\text { to, and corporate } \\
\text { accountability } \\
\text { for, climate } \\
\text { change in } \\
\text { Bangladesh. } \\
\text { Environmental } \\
\text { Development and } \\
\text { Sustainability, } 18 . \\
\text { Pp. 157-186. }\end{array}$ & $\begin{array}{l}\text { structured } \\
\text { interviews and } \\
71 \text { annual } \\
\text { reports. }\end{array}$ & $\begin{array}{l}\text { attention to } \\
\text { climate change } \\
\text { than others and } \\
\text { consequently, } \\
\text { they care more } \\
\text { about climate } \\
\text { change } \\
\text { reporting. The } \\
\text { author also has } \\
\text { asserted that } \\
\text { multinational } \\
\text { companies } \\
\text { provide } \\
\text { unsatisfactory } \\
\text { disclosure on } \\
\text { climate change } \\
\text { in the } \\
\text { Bangladeshi } \\
\text { market. }\end{array}$ & $\begin{array}{l}\text { creating a guiding } \\
\text { framework for } \\
\text { much more } \\
\text { organized climate } \\
\text { change reporting. }\end{array}$ \\
\hline
\end{tabular}

Source: prepared by the author

Despite the role climate change plays in shaping production and consumption practices in individual companies and also supply and demand in different markets (Gonzalez- Gonzalez \& Ramirez, 2016), this was merely touched upon in a few studies addressing the association or relationship between climate change and other HR or organizational aspects (e.g. organizational commitment, organizational engagement, organizational citizenship behaviour, organizational silence, organizational cynicism and so on). Moreover, the only two studies addressing the effect of climate change on organizational aspects or the effect of organizational phenomena on climate change, focus solely on organizational communication and the extent to which organizations disclose much more reports on climate change when they engage in voluntary tailor-made communication (Ferguson et al., 2016).

Clearly, tailor-made organizational communication reflects the free ability of every organization to choose its own linguistic strategies when reporting on climate change. Gonzalez-Gonzalez and Ramirez (2016) have addressed the best approach in communicating carbon emissions and that this kind of communication should fit every company system of reporting. In the academic sense, the author of this paper explores the fact that addressing the relationship between climate change and organizational aspects entails adopting the following academic theories. 
- Legitimacy theory: Deegan (2002) highlights that legitimacy theory is considered when discussing the environmental and social behaviour of organizations. Hogner (1982) indicates that the environmental behaviour of organizations and subsequent disclosure often comes as a result of societal expectations of organizational practices. Dowling and Pfeffer (1975, P. 172) have defined organizational legitimacy as "a condition or status, which exists when entity's value system is congruent with the value system of the large social system of which the entity is part." In regard to this theory, the organization should consider adapting to climate change as a main part of its behaviour and subsequently should disclose full reports. This adds value to the organization by showing how socially responsible it is, and consequently, this may affect the positive phenomena (e.g. trust, loyalty and citizenship behaviour) and the negative phenomena (e.g. organizational silence) of organizational human resources.

- Stakeholder theory: according to Harrison et al. (2010), the organization should work not only in the interests of the shareholders, but also for their internal and external stakeholders, such as employees, suppliers, governments and so on. According to this theory, the organization can increase its credibility by mitigating the effects of climate change and provide different stakeholders with all the required information. Needless to say the human resources in every company forms the main part of its stakeholders. Accordingly, addressing the issues of climate change, especially those results from human activities, such as increasing carbon emissions, may result in a kind of satisfaction for employees at different levels.

Moreover and owing to the difficulty of anticipating the location, duration and scale of any climate- related symptoms, Winn et al. (2011) highlight that uncertainty is one of the main features distinguishing climate change. It is important to add that it is even more difficult to predict the consequences or risks of climate change in and within the organizational or corporate world, particularly in respect to HR (e.g. commitment, involvement, trust, presence, engagement, turnover etc.). Harrison and Kelly (2010) therefore assert that nature is considered a primary source of organizational uncertainty. Furthermore, Bordia et al. (2004) highlight that the natural environment is a fact of strategic uncertainty and the lack of information about it may even change the 
direction of organizations in addition to both current and potential orientations. It is worth mentioning that Mousa (2016) has empirically proven that strategic uncertainty, which includes the natural environment as one of its main facets, negatively correlates with employee organizational commitment. In addition, another study conducted by Mousa and abdel-Gaffar (2017) has touched upon the relationship between uncertainty and organizational cynicism and shown no correlation between strategic uncertainty and employee organizational cynicism. Moreover, Winn et al. (2011) clarify that climate change constantly leads to massive organizational change, and subsequently, organizations should be aware of the dynamics of managing sustainability, crisis and risks in order to manage both the challenges and opportunities of climate change. Consequently, there is nothing that could justify this intentional and/or unintentional absence of the concept of climate change from the academic literature on organizational and human resources management.

\section{Discussion, and Conclusions}

Despite the importance of climate change in deciding on current and future choices for organizations, there is a scarcity of research addressing the relationship between the changing climate and organizational aspects (e.g. organizational commitment, organizational engagement, organizational involvement etc.). Upon elaborating the importance of this phenomenon and touching upon its potential risks for many industries and business fields, the author of this paper urges HR and organizational scholars to pay more attention to this topic/phenomenon and devote considerable space to examining its effect on employee trust, work stress, job satisfaction, turnover, intentions to leave, absenteeism, job-roles and others. 


\section{References}

[1] Banerjee, S.B. (2003). Who sustains whose development? Sustainable development and the reinvention of nature. Organization studies 24 (1), 143-180.

[2] Begum, R.A. \& Pereira, J.J. (2011). Corporate perceptions of climate change in Malaysia. African journal of business management 5 (11), 4299-4305.

[3] Begum, R.A. \& Pereira, J.J. (2015). The awareness, perception and motivational analysis of climate change and business perspectives in Malaysia. Mitig adapt strategy glob change 20, 361-370.

[4] Bordia, P., Hobman, E., Jones, E., Gallios, C. \& Callon, V. (2004). Uncertainty during organizational change: types, consequences and management strategies. Journal of business and psychology 18 (4).

[5] Deegan, C. (2002). Introduction the legitimizing effect of social and environmental disclosures- a theoretical foundation. Accounting, auditing and accountability journal 15 (3), 282-311.

[6] Dowling, J. \& Pfeffer, J. (1975). Organizational legitimacy societal values and organizational behavior. Pacific sociological review 18 (1), 122-136.

[7] Ferguson, J., Aguiar, T.R.S.D. \& Fearfull, A. (2016). Corporate response to climate change: language, power and symbolic construction. Accounting, auditing \& accountability journal 29 (2), 278-304.

[8] Gonzalez- Gonzalez, J.M. \& Zamora- Ramirez, C. (2016). Organizational communication on climate change: the influence of the institutional context and the adoption pattern. International journal of climate change strategies and management 8 (2), 286-316.

[9] Harrison, J. \& Kelly, S. (2009). Perceived environmental uncertainty's effect on commitment in business- to- business channels. Marketing intelligence and planning 28 (6).

[10] Harrison, J.S. \& Bosse, D.A. (2013). How much is too much? The limits to generous treatment of stakeholders. Business horizons 56 (3), 313-322.

[11] Harrison, J.S., Bosse, D.A. \& Phillips, R.A. (2010). Managing for stakeholders, stakeholder utility functions and competitive advantage. Strategic management journal 31, 58-74.

[12] Hoffman, A.J. (2006). Getting ahead of the curve: corporate strategies that address climate change. Prepared for the Pew center on global climate change. Cited in Okereke, C. 2007. An exploration of motivations, drivers and barriers to carbon management: The UK FTSE 100. European management journal 25 (6), 475-486.

[13] Hoffmann, V., Sprengel, D., Ziegler, A., Kolb, M. \& Abegg, M. (2009). Determinants of corporate adaptation to climate change in winter tourism: an econometric analysis. Global environmental change 19, 256-264.

[14] Hogner, R.H. (1982). Corporate social reporting: eight decades of development at US steel. Research in corporate performance and policy 4, 243-250.

[15] Hrasky, S. (2012). Carbon footprints and legitimation strategies: symbolism or action? Accounting, auditing and accountability journal 25 (1), 174-198.

[16] Kiron, D., Kruschwitz, N., Haanaes, K. \& Fuisz-Kehrbach, S.K. (2013). How serious is climate change to business?. MIT Sloan management review 55 (1), 74-76. 
[17] Linnenluecke, M. \& Griffiths, A. (2012). Assessing organizational resilience to climate and weather extremes: complexities and methodological pathways. Climatic change 113, 933-947.

[18] Marquis, C. \& Qian, C. (2014). Corporate social responsibility reporting in china: symbol or substance? Organization science 25 (1), 127-148.

[19] Mousa, M. \& Abdelgaffar, H.A. (2017). A float over uncertainty and cynicism: an experience from Egypt. Journal of commerce and management thought 8 (3), 508- 530.

[20] Mousa, M. \& Alas, R. (2016). Uncertainty and organizational commitment: a study on primary public schools' teachers in Menoufia (Egypt). European Journal of Business and Management 8 (20), 38- 47.

[21] Nurunnabi, M. (2016). Who cares about climate change reporting in developing countries? The market response to, and corporate accountability for, climate change in Bangladesh. Environ Dev Sustain 18, 157-186.

[22] Saba, A., Biasutti, M., Gerrard, M.B. \& Lobell, D.B. (2013). Getting ahead of the curve: supporting adaptation to long- term climate change and short- term climate variability alike. CCLR 1, 3-23.

[23] Spence, C. (2007). Social and environmental reporting and hegemonic discourse. Accounting, auditing and accountability journal 20 (6), 855-882.

[24] Sullivan, R. (2010). An assessment of the climate change policies and performance of large European companies. Clim pol 10 (1), 38-50.

[25] Vaara, E., Sorsa, V. \& Palli, P. (2010). On the force potential of strategy texts: a critical discourse analysis of a strategic plan and its power effects in a city organization. Organization 17 (6), 685-702.

[26] Winn, M.I., Kirchgeorg, M., Griffiths, A., Linnenluecke, M. \& Gunther, E. (2011). Impacts from climate change on organizations: a conceptual foundations. Business strategy and the environment 20, 157-173.

[27] Zakaria, M. (2015). Knowledge management and global climate change regime negotiations. Foresight 17 (1), 53-62. 